\title{
Social learning in transnational projects - lessons from European territorial cooperation projects
}

\author{
Jörn Harfst, David Osebik \\ Envigogika 10 (1) - Case Studies/ Prípadové studie
}

Published/ Publikováno 25. 4. 2015

DOI: $10.14712 / 18023061.432$

\begin{abstract}
Old industrial regions in Europe have undergone radical changes in the last decades. After downsizing or closure of predominant industries such regions usually face big challenges concerning their economic, social and ecological futures. One chance to master this transformation process is the identification and sustainable utilisation of potentials left by industrial production. Utilisation of regional potentials, commonly categorized as natural and cultural potentials, was the aim of two transnational cooperation projects ReSource and SHIFT-X, which were both funded by European Union's Development Fund (ERDF, INTERREG IVB).

The paper shows how the involvement of research partners in the projects supported and facilitated joint learning effects and knowledge transfer between all project partners. It is argued that on the one hand such an approach offers important mutual benefits for partners, while on the other hand the realisation of such benefits remains a challenging task in a transnational collaboration. In declining industrial regions, especially when characterised by small- and medium-sized towns, the capacities to act are scarce and any outside intervention is often seen more as an unwanted factor that additionally stretches resources and provides little advantages for such regions. Therefore one of the main aims in transnational collaboration has to be the establishment of a trustful and committed working relation between all partners. The engagement in the projects has shown that the joint work between regional actors and the external academic partners can create important transnational learning effects for all involved; nevertheless it has to overcome certain reservations on all sides before innovative ways can be pursued successfully.
\end{abstract}

\section{Key Words}

Regional Development; Old Industrial Regions; Regeneration; Strategy Development; Social Learning

\begin{abstract}
Abstrakt
Staré průmyslové regiony $v$ Evropě prošly $v$ posledních desetiletích radikálními změnami. Poté, co $v$ nich převažující průmyslová odvětví byla omezena nebo uzavřena, tyto regiony obvykle čelí velkým potízím, které mají vliv na jejich ekonomickou, sociální a ekologickou budoucnost. Jednou z možností, jak podpořit proces jejich transformace, je
\end{abstract}


určit a udržitelným způsobem využívat to, co po sobě průmyslová výroba zanechala. Takové využití regionálního potenciálu, obecně označovaného jako jejich přírodní a kulturní bohatství, bylo cílem dvou projektů mezinárodní spolupráce ReSource a Shift-X, které byly oba financovány Fondem Evropské unie pro rozvoj (EFRR, INTERREG IVB).

Článek ukazuje, jak zapojení výzkumu v podporovaných projektech nastartovalo společné učení - podpořilo předávání znalostí mezi všemi partnery projektu. Autoři argumentují, že na jedné straně tento přístup nabídl partnerům důležité vzájemné výhody, přitom však na druhé straně dosáhnout těchto výhod bylo dosti náročným úkolem mezinárodní spolupráce. $V$ upadajících průmyslových regionech, zvláště těch, kde jsou zastoupeny jen malé a střední obce, jsou kapacity omezené a jakýkoliv vnější zásah je často chápán spiše jako nežádoucí faktor, který dále omezuje zdroje a poskytuje málo výhod pro samotné regiony. Proto jedním z hlavních cílů mezinárodní spolupráce musí být vytvoření důvěry a založení pracovního vztahu mezi všemi partnery. Zapojení do projektů ukázalo, že společná práce regionálních aktérů a vnějších akademických partnerů může mít významný vliv na učení všech zúčastněných; přesto musí překonávat určité výhrady $z$ jejich strany, než Ize úspěšně pokračovat v žádoucích inovacích.

\section{Klíčová slova}

Regionální rozvoj; Staré průmyslové regiony; Regenerace; Rozvojové strategie; Sociální učení 


\section{Introduction}

Many European industrial regions have undergone radical changes in recent decades. These transformations have had a profound impact on affected regions and towns, which had been shaped by these industries for centuries. In many cases the downsizing or closure of major industrial production sites meant de-industrialisation, high unemployment and out-migration, leaving especially regions characterised predominantly by small and medium-size towns to face enormous challenges for their economic, social and environmental futures (Eckart, 2003). Therefore affected cities and regions often have to re-invent themselves. Creative concepts are needed as well as a change of strategies and sound investigation of feasibility, in order to support post-industrial regions to catch up in competitiveness and to move towards innovative and sustainable development options (Cooke, 1995).

Success or failure of such structural transformation processes is often strongly linked to the actions of local and regional actors and their ability to realize chances and potentials in such restructuring processes (Marot \& Harfst, 2012). Therefore it is necessary to develop a conceptual approach supporting the efforts of affected local authorities and regional initiatives. This article will reflect on the experiences from two European projects, where the authors have worked along actors in old-industrial regions supporting their search for new development options. The aim of the research was to stimulate the regional learning process in order to enable local actors to develop projects that use potentials in innovative ways, thereby strengthening their overall development capacities (Harfst, Wirth, \& Lintz, 2012).

Both the 'ReSource' (2009-2012) and 'SHIFT-X' (2012-2014) projects were funded by the European Regional Development Fund (ERDF) in accordance with the European Union's objective 3 "territorial cooperation" (INTERREG IVB, Central Europe programme) and engaged partners from different central European countries.

\section{Role of Research}

The most innovative aspect of both projects was the close interconnection of research and practical development initiatives within the regions. This connection has created a valuable opportunity to "professionalize" the transnational knowledge transfer by involving academics and their knowledge. The involvement of researchers also provided the regions with an external view on their problems and in this way supported and enhanced their search for new development paths. The research agenda of the projects has loosely followed an "action research approach" (Greenwood \& Levin, 2007), incorporating the research partners in practical tasks with regional actors, but also enable them to reflect on the overall aims of the project. The methodology of the approach has been described in some detail elsewhere (Osebik \& Harfst, 2011).

One of the biggest challenges lies in bringing practice and research together, in order to create 'real' mutual benefits. Both projects have met this challenge by applying a lot of effort to integrate these two fields in the project design and the accompanying scientific concept (see Figure 1). In order to avoid a situation of two more or less separately acting working groups, a twofold design about the responsibilities and main tasks of the academic sphere has been defined (Harfst, Wirth, \& Lintz, 2009, p.6ff). 
Figure 1: Twofold task structure of research within ReSource (Harfst, Wirth, \& Lintz, 2009)

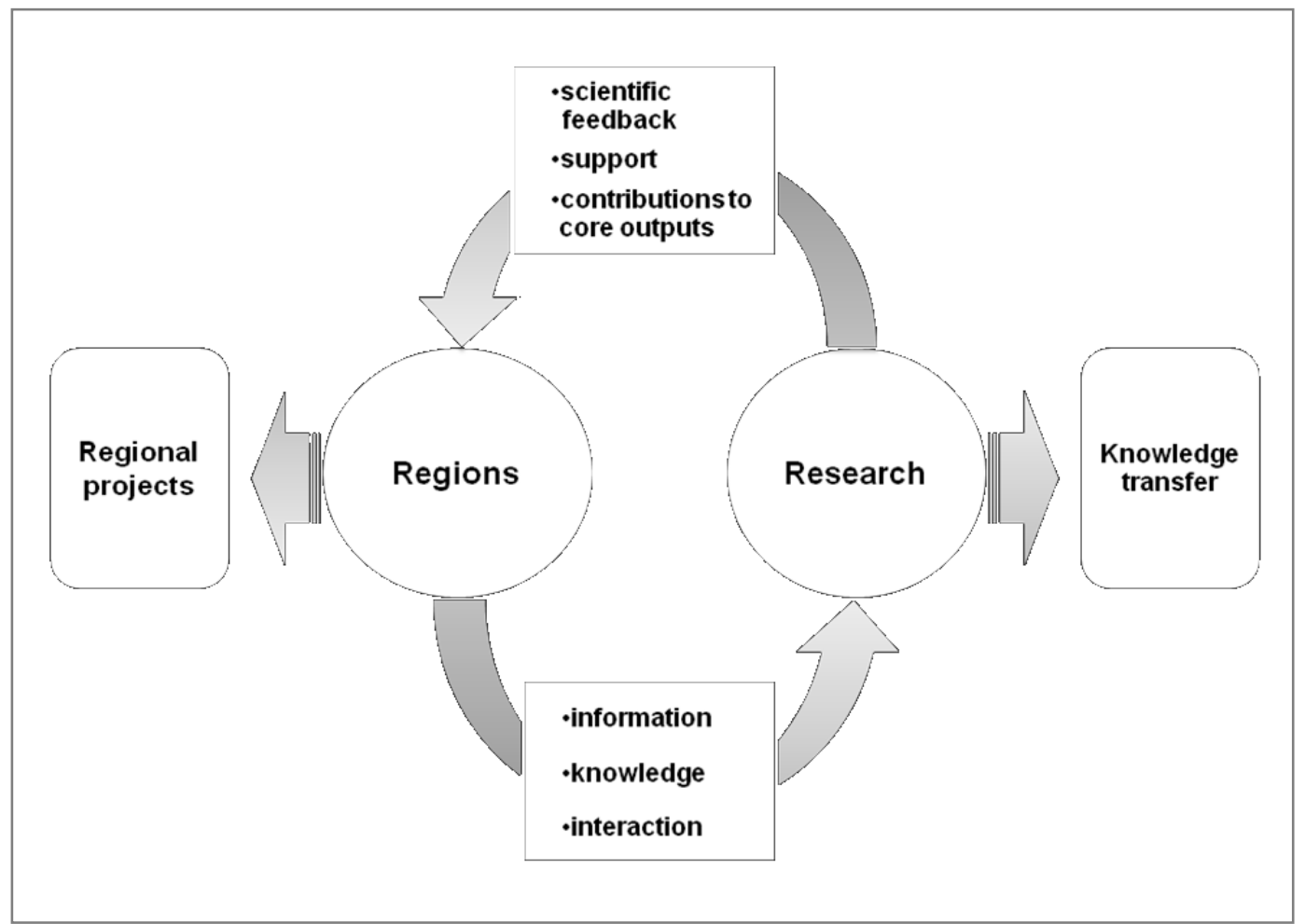

The generation of knowledge represents the main task of research within the project, while regional partners focused on practical projects or concept development. The focus of investigation primary lies on the finding, assessment and valorisation of regional potentials as well as on regional framework conditions (actors and interplay of change), which finally determine the overall development process. Results of the academic work are constantly provided to the partner regions (symposia, workshops, informal meetings, reports etc.) and to a broader public (press releases, public conferences etc.). To foster such learning effects further thematic working groups have been established in course of the project. They enhanced thematic discussion on particular issues (e.g. utilisation of specific potentials) and bound involved partners closer together by encouraging mutual exchange of experiences on a practical and output-orientated basis. Overall these measures provided a good basis for mutual support, exchange of experiences and further cooperation with an overall focus on raising the organisational capacities of the involved regions (Harfst \& Marot, 2013).

\section{Working with Actors in Old Industrialised Regions}

An important factor in any regional setting is the local and regional stakeholder network that shape development processes. In old industrial regions - especially in regions with predominantly small- and medium-sized towns - often exist strong and tightly-knit networks (Grabher, 1993). When regional key actors are able to join forces on development issues, this often means good access to external funding and local consensus, creating an essential element for a new development path. 
On the other side old industrial regions are often not in a situation that supports creative and sustainable solutions for future development. Generally such regions face various economic, social and environmental challenges (i.e. unemployment, outmigration, pollution), which hamper or block new development options by creating unfavourable conditions for new investment (i.e. poor image, brownfields etc.). These multiple issues tend to overwhelm local actors and paralyze stakeholders. Often existing networks can become harmful to the development of such regions, as they are often unable to allow new actors with new ideas into the process of regional development ("lock-in" effects) (Grabher, 1993; Harfst, Wirth, \& Lintz, 2012). Such regions face the danger to become caught in a circle of dependency on financial support from external sources and a nostalgic worldview, where a longing for the "good old times" form part of a backward attitude. In this respect it seems important to mention, that it is unrealistic to assume that any (shortterm) restructuring might lead back to the unemployment and growth level of the peaktime of industrial production. Therefore a deep and long sighted process of planning is necessary to establish a realistic starting point for sustainable regional development (Harfst, Fischer, \& Wirth, 2012).

\section{Success factors and constraints of transnational projects}

\section{Combining different levels of knowledge}

Both projects have focused on regional capacity building for innovation and change, a key aspect of the EU's transnational cooperation projects. ReSource focused more on the identification of regional potentials, while SHIFT-X highlighted the utilisation of industrial heritage as one specific element (for more information see www.resource-ce.eu and www.shiftx.eu ).

By incorporating researchers along regional partners in both projects, another level of knowledge exchange within the project setup was added. Now not only regions were able to exchange practical experiences with each other, but also the academic partners were able to compare research findings among them. For example in the ReSource project the research consortium included 6 different academic institutions from different countries, each covering at least one of the 7 involved regions in the project. The project setup also saw researchers working closely along regional partners on a practical day-to-day basis, e.g. by compiling information and benchmarks for reports and regional concepts (i.e. on European 'good practice' examples), moderating workshops in the regions and providing additional knowledge to the project by inviting outside experts from their own network. Another important element of mutual support and exchange were the three thematic work groups within each of the projects, where partners explored different topics together (i.e. natural potentials like geothermal energy in ReSource or new museum management concepts in SHIFT-X). All these approaches held the possibility to create different learning effects for all participants (see Figure 2). Besides these formal project activities, the partnership encouraged bilateral meetings and visits of partners, in order to ensure lasting network connections, even beyond the project run-time. 
Figure 2: Levels knowledge exchange and cooperation

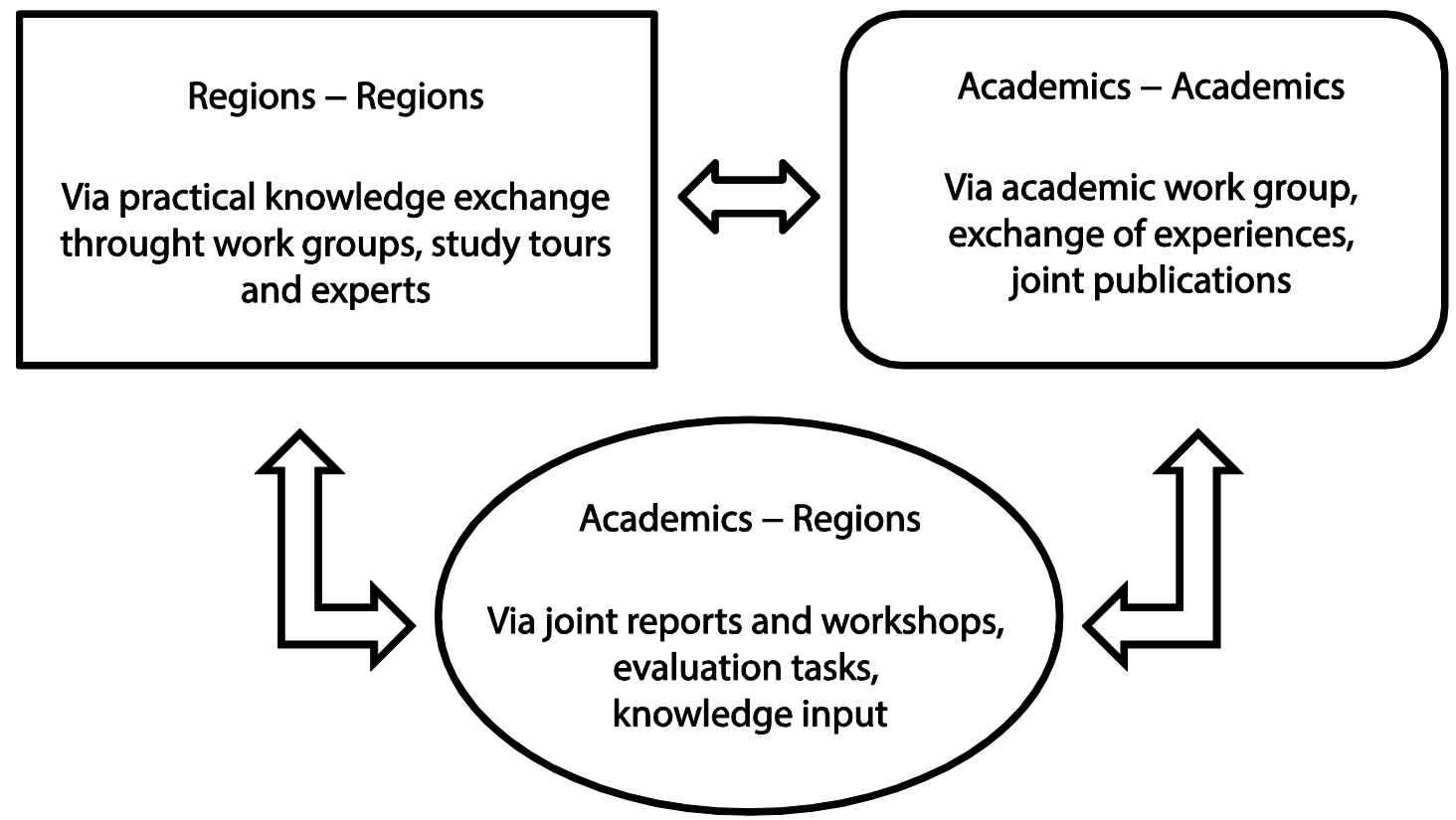

Nevertheless with both the ReSource and SHIFT-X project each only covering a three year period and with limited financial resources, every project agenda has to face certain limitations. Especially the time factor confines the initiatives set by regional and academic partners, limiting the possibility to prepare ready-to-use solutions and providing sustainable regional development at one stroke. Such transnational projects are often more a starting point for initiating a consciousness about existing potentials and future options in the involved regions. Therefore it depends on every single project partner, regions as well as academic institutions, to make use of project results and continue the initiated cooperation proactively. In this sense the "unofficial" task of the project is to establish a self- organizing network of mutual exchange of knowledge and experience, which raises the long-term capacities of all partners involved.

\section{Involving different institutions and people}

Bringing together different regional actors and researchers from various countries and backgrounds presents a big challenge to any project and its management. Different development levels regarding the transformation process, varying national framework conditions (financial support, legal situation, political awareness etc.), as well as specific regional problems (e.g. environmental damages, peripheral location, and regional specifics) make the transferability of results on a regional level somewhat problematic. Additionally even research-wise the approaches and understandings towards regional development issues tend to differ between institutions.

Also to involve the 'real' local experts on certain issues into the project has posed a constant challenge. The regular regional representatives within the project meetings are often from administration and therefore not involved in practical issues like heritage management or museums. But the real knowledge exchange should happen on the practical level, so additional efforts in time and money have to be made in order to get the 
'right' people together. By doing so, new organisational problems can arise (i.e. language barriers). Additionally on the more personal side, partners have to overcome local pride and mental reservations to make use of each other's experiences. While research and regional partners sometimes find it difficult to speak the same 'language', own experiences from the projects have shown, that good partnership needs trust and the will to cooperate. In some cases, regional actors tend to present their home region rather from the good side, before discussing the real problems.

For involved researchers, one of the biggest challenges is to get a good insight into the regions they are working with. As described above, academic partners strongly depend on information and experience of regional partners and vice versa. It is up to the academic partners to establish an atmosphere of mutual trust. Speaking the same "language", as well as making regional partners understand what researcher can contribute to them, is a very important social task. Additionally some regions have already established a deep organisational network and knowledge-base, so that further outside interference by researchers is seen as unnecessary or even unwanted. This is connected with another academic challenge, which concerns the insight in the regional network of actors and power relationships. All project regions have a tight and exclusive organisation structure, which makes it sometimes difficult for researchers to investigate the interplay and real importance of actors.

\section{Conclusions}

Revitalization of former or declining industrial regions can be seen as an attempt of turning a fish soup into an aquarium. Besides the above described disadvantageous physiognomic situation after the end of large scale industrial production, the first challenge for such regions is to overcome old paradigms and the therewith connected paralysation of local innovation. Therefore the role of research within transnational cooperation projects is clearly defined as a supporting partner in a regional learning process, which aims to find a different and innovative angle on the industrial heritage and its potentials. And this is somewhat difficult: Tight and traditional networks of actors, narrow foci, outmigration of especially younger population, an overall inaccessibility for external or new actors plus several additional factors hamper the necessary paradigm shift. Academic partners can help to mitigate this challenge by giving continuous evaluation and assessment, theoretical support, experience from similar projects, benchmarks with other regions and lastly by common learning activities and events. In regard to this, the projects ReSource and SHIFT-X both tried to interconnect practice (regions) and science (academic partners) with gains for all involved. This has to been seen as an ambitious task that is not simply created by joining different partner in one project, but requires social and learning skills by everybody involved. Nevertheless such cooperation holds the possibility of opening new dimensions of knowledge exchange and learning for all involved. The partnership not only provided regions with new concepts and pilot investments, but also reached beyond the project context by spreading results to the scientific community (publications), as well as to policy makers via making strategic recommendations and organising conferences and networking events. 


\section{Acknowledgements}

The authors are grateful for the financial support of the European Union through it ERDF funding for both the mentioned projects, as well as the good collaboration with academic and regional partners within the project.

Development of the former version of the case study has been supported from the project OP VK CZ.1.07/2.4.00/17.0130 "Interdisciplinary Network for Policy Development in Sustainable Development Field" funded through the Education for Competitiveness Operational Programme via the Czech Ministry of Education, Youth and Sport.

\section{References}

- Cooke, P. (1995). Rise Of The Rustbelt: Revitalizing Older Industrial Regions (1st ed.). Routledge.

- Eckart, K. (Ed.). (2003). Social, economic and cultural aspects in the dynamic changing process of old industrial regions. Ruhr District (Germany), Upper Silesia (Poland), Ostrava Region (Czech Republic). Münster: LIT.

- Greenwood, D. J., \& Levin, M. (2007). Introduction to Action Research: Social Research for Social Change. SAGE Publications.

- Harfst, J., Fischer, W., \& Wirth, P. (2012). Reflection on Strategic Options for PostMining Development. In Post-Mining Regions in Central Europe (p. 242ff).

München: OEKOM.

- Harfst, J., \& Marot, N. (2013). Capacity-Building in Old Industrialised Regions: A Success Factor in Regional Development? In Capacity Building and Development: Perspectives, Opportunities and Challenges (pp. 117-134). Nova Publishers.

- Harfst, J., Wirth, P., \& Lintz, G. (2009). Scientific Concept of the ReSource Project - "Roadmap." Leibniz Institute of Ecological and Regional Development (IOER). Retrieved from http://www2.ioer.de/recherche/pdf/2009_harfst_resource_road_map.pdf

- Harfst, J., Wirth, P., \& Lintz, G. (2012). Governing Post-Mining Potentials: The Role of regional Capacities. In Post-Mining Regions in Central Europe (pp. 168-181). München: OEKOM.

- Marot, N., \& Harfst, J. (2012). Post-mining potentials and redevelopment of former mining regions in Central Europe - Case studies from Germany and Slovenia. Acta Geographica Slovenica, 99-119. doi:10.3986/AGS52104

- Osebik, D., \& Harfst, J. (2011). The ReSource Project. Turning Problems into Potentials. In A. Barton \& J. Dlouhá (Eds.), Multi-Actor Learning for Sustainable Regional Development in Europe. A Handbook of Best Practice (pp. 183-199). 
Jörn Harfst, University Graz, Institute of Geography and Regional Science, j.harfst@uni-graz.at ${ }^{1}$

David Osebik, University Graz, Institute of Geography and Regional Science, d.osebik@uni-graz.at

${ }^{1}$ Corresponding author 